\title{
The Study on Energy Independence (Autonomy) of an Agricultural Enterprise Assurance
}

\author{
Natalia Pryshliak ${ }^{1}$, Natalia Zdyrko ${ }^{2}$, Andrii Shynkovych ${ }^{1}$, Natalia Koval ${ }^{1}$ \\ ${ }^{1}$ Department of Administrative Management and Alternative Energy Sources, Vinnytsia National Agrarian \\ University, 21008, 3 Sonyachna Str, Vinnytsia, Ukraine \\ ${ }^{2}$ Department of Accounting and Auditing, Vinnytsia National Agrarian University, 21008, 3 Sonyachna Str, \\ Vinnytsia, Ukraine
}

\begin{abstract}
Ukraine's agriculture plays a leading role in ensuring the country's food and energy security through its bioenergy potential. Although, having significant available biomass of agricultural production, the country's agricultural sector demonstrates the slow development of enterprises and production of final products - biofuels. The use of the bioenergy potential of agriculture is seen as one of the components of the strategy of sustainable development. The practical value of the study is reflected in the fact that government bodies can use the results of the study to improve the activities of domestic agricultural enterprises and to develop biofuel production from agrobiomass waste. The study shows what aspects need to be improved, and draws the attention of the management of agricultural enterprises to review some of the features of the production and use of biofuels in order to ensure the level of their energy autonomy and enable them to achieve the goals of ensuring and increasing the efficiency of the main production.

The purpose of this study is to investigate the potential, awareness and current state of agricultural
\end{abstract}

DOI: 10.18421/TEM111-51

https://doi.org/10.18421/TEM111-51

Corresponding author: Natalia Pryshliak,

Department of Administrative Management and Alternative Energy Sources, Vinnytsia National Agrarian University, 21008, 3 Sonyachna Str, Vinnytsia, Ukraine.

Email: pryshliak.vnau@gmail.com

Received: 06 November 2021.

Revised: 07 February 2022.

Accepted: 14 February 2022.

Published: 28 February 2022.

(cc) BY-NC-ND (C) 2022 Natalia Pryshliak et al; published by UIKTEN. This work is licensed under the Creative Commons Attribution-NonCommercial-NoDerivs 4.0 License.

The article is published with Open Access at https://www.temjournal.com/ waste in small and medium-sized agricultural enterprises, using the most acceptable, appropriate and reliable way.

Keywords - agrobiomass, waste, biofuel, biogas, energy autonomy.

\section{Introduction}

Now there is a lot of experience in the use of agricultural waste for energy purposes. The energy sector has a real prospect of gradually replacing fossil fuels with biofuels made from agrobiomass in transport, industry and utilities. Biofuels have been introduced 25 years ago and its use has shown constant increase [6]. More and more countries are developing the production of biofuels on an industrial scale and are developing national programs for the development of bioenergy at the state level. Biofuels are an outstanding instance of renewable energy which can be produced using biological organisms which will ultimately cause a reduction in dependence on fossil fuels [7]. Unfortunately, the pace of bioenergy development in Ukraine lags far behind world indicators.

In modern conditions, agriculture uses technological processes that generate significant amounts of waste. Inefficient waste management often has negative environmental consequences. The problem of agricultural waste in Ukraine is of particular importance due to the lack of timely response to the challenges associated with inefficient waste management. Powerful volumes of resource use of the national economy in combination with outdated technological base cause high rates of waste generation and accumulation. Uncontrolled and increasing accumulation of waste leads to an exacerbation of the environmental crisis and the deterioration of the socio-economic situation in society. These factors necessitate the reform and development of the waste management system taking into account domestic and international experience, as well as 
the legal and economic system governing the use of natural resources in general and agrobiomass waste management in particular. The high level of agricultural waste generation and the low efficiency of their use as secondary resource have led to the fact that in Ukraine annually significant volumes of agrobiomass waste accumulate in agriculture, which is why only a small part is being used as feedstock for the production of biofuel, the rest is accumulated in open space. At the same time, harmful substances enter the soil and groundwater, polluting the environment.

The study reflects the assessment of the problem of awareness of managers of small and medium-sized agricultural enterprises regarding the potential, awareness and current state of the use of agricultural waste, using the most acceptable, appropriate and reliable way.

\section{Literature Review}

The development of conceptual bases and scenarios of modelling of environmental safety in the system of sustainable development today is an important direction of researches [11]. Biofuel production and waste-free technologies make a significant contribution to environmental and energy security as components of sustainable development.

Issues related to biofuels are widely studied in the world, taking into account the supply and demand of the energy resources market, expectations regarding the further development of the bioenergy sector, as well as greenhouse gas emissions. At the same time, the classification of various types of biofuels has been actively carried out to meet the needs of transport. Predictions of future trends in biofuel demand and the long-term potential for the production and use of biomass and biofuels are high on current research.

Biomass is used all over the world for the production of thermal energy as well as for the operation of transport [8]. Adequate resources are needed to increase biomass production in the future. There are many studies currently underway to determine and predict the future availability of biomass, but the results of such studies are not unambiguous [22].

Most of the studies carried out have focused on the assessment of the "technical potential of biomass", which determines the amount of biomass for energy use according to the technical framework conditions [16]. The limitations of such research include different criteria based on structural, legal, environmental or social factors. Since the technical potential is sufficiently stable over time, it is often widespread to represent the potential of biomass [23].
A wide range of problematic issues, the lack of systemic knowledge about the possibilities of using and methods of producing biofuels based on the processing of waste from agricultural enterprises, as well as the inconsistency of political goals and business interests related to problematic aspects of biofuel production and its use, mean that interest in these issues is growing [8].

Various waste management scenarios are being implemented today, including the energy use. One of the directions of the innovation scenario for the development of solid domestic waste management is the use of the organic part of waste from landfills for biogas production [1]. Biogas production is an important area of providing agricultural enterprises with energy resources.

Compared to the current state of the use of biomass for energy supply, studies by many scientists indicate a slight increase in the near future, but the results also contain some differences, especially in the expected potential of energy crops [20].

This is largely the case for first-generation biofuels made from energy crops. An additional source of biomass is forests and lignocellulosic biomass residues, for which biofuel processing technologies are still being developed [21].

The most important drivers of uncertainty in this area are the growth of world population and food consumption per capita, driven by world economic development. An important factor is the growth in food, feed and biomass production. Climate change also has a significant impact on agricultural production, but the impact is difficult to quantify [14].

Reducing the availability of land is an important factor in the formation of biomass potential. This decrease can be the result of land degradation, urban sprawl and inappropriate agricultural practices. Land loss is expected to reach $20 \%$ by 2050 [15].

By expanding the resource base for the production and consumption of biofuels, there is a transition from the production of heat and / or electricity to the actual production of biofuel. For this, the necessary conditions are the availability of production equipment and technologies and the ability to administer and manage production. Many countries around the world intend to increase their own bioenergy resources [5]. It is also worth adding that the availability of biomass from other sources remains limited [24].

Biomass production processes are characterized by a significant number of disadvantages, as evidenced by the results of many studies on the energy and economic efficiency of growing bioenergy crops. In this context, significant attention is required for measures to increase the yield of these crops. 
The use of energy crops as a feedstock for biofuel production has a number of advantages, which include: the possibility of natural gas substitution, reducing the cost of energy, land reclamation, decarbonization, reducing emissions, and economic growth [10].

Valuable contribution to the study of biofuel production and consumption in Ukraine has been made by scientists at Vinnitsa National Agrarian University. Various scientists studied state regulation in agriculture and biofuels sector of Ukraine, as well as world experience in this field [17], [18], [20].

This study is the continuations of previous researches of the authors [19]. The greatest problematic aspect in this area remains the search for a way to ensure the economic efficiency of biofuels and energy autonomy of production, while maintaining environmental friendliness and, in particular, social responsibility. If these issues are resolved, the global energy profile will change for the better. Also, key factors can affect trade, since almost identical energy sources can be obtained domestically, rather than imported from abroad. Now, researchers around the world continue to invest time and money in finding ways to ensure economic efficiency of biofuels and energy autonomy of production.

\section{Materials and Methods}

Based on the results of previous research [19], the hypotheses of our study can be formulated as follows:

H.1. Agricultural enterprises spend significant funds on the purchase of fuel and energy resources, which affects the cost of final products.

H.2. Agricultural enterprises have a significant potential for crop waste and livestock byproducts for biofuel production.

H.3. The bioenergy potential of agricultural enterprises is represented by the feedstock component (waste that can be used for biofuel production).

H.4. The available bioenergy potential is practically not used.

H.5. The level of awareness about the possibilities of waste-based biofuel production is low; it is slightly higher among managers under the age of 45 and with higher education.

H.6. The main source of information on the possibilities of energy use of waste is the media.

H.7. The heads of enterprises do not have information about state support for bio-production at a level sufficient for practical activity (legislation, support programs, tax and other benefits, "green" tariff, the possibility of using credit support from international financial organizations).
In the context, the potential, awareness and current state of the use of agricultural waste to ensure the energy autonomy of agricultural enterprises can be explored with two approaches: a professional technical approach, and a professional administrative approach. The potential, awareness and current state of the use of agricultural waste are determined in accordance with a technical approach, taking into account the technologies of harvesting bioenergy crops and their processing into energy in accordance with the latest world developments, scientific methods and experience. As for the professional administrative approach, it reflects how effectively the resources available in agricultural enterprises have been used to ensure their energy autonomy.

The research model, as summarized in Figure 1, examines the impact of measuring the potential, awareness, readiness and current state of use of agricultural waste on the energy independence of the agricultural enterprise. The potential of the enterprise for the production and use of biofuels is characterized by awareness in the field of production and use of biofuels; readiness of the production base of the enterprise for the production and use of biofuels; readiness of the administrative staff of the enterprise for the production and use of biofuels; the state of implementation of biofuel production in an agricultural enterprise; social responsibility.

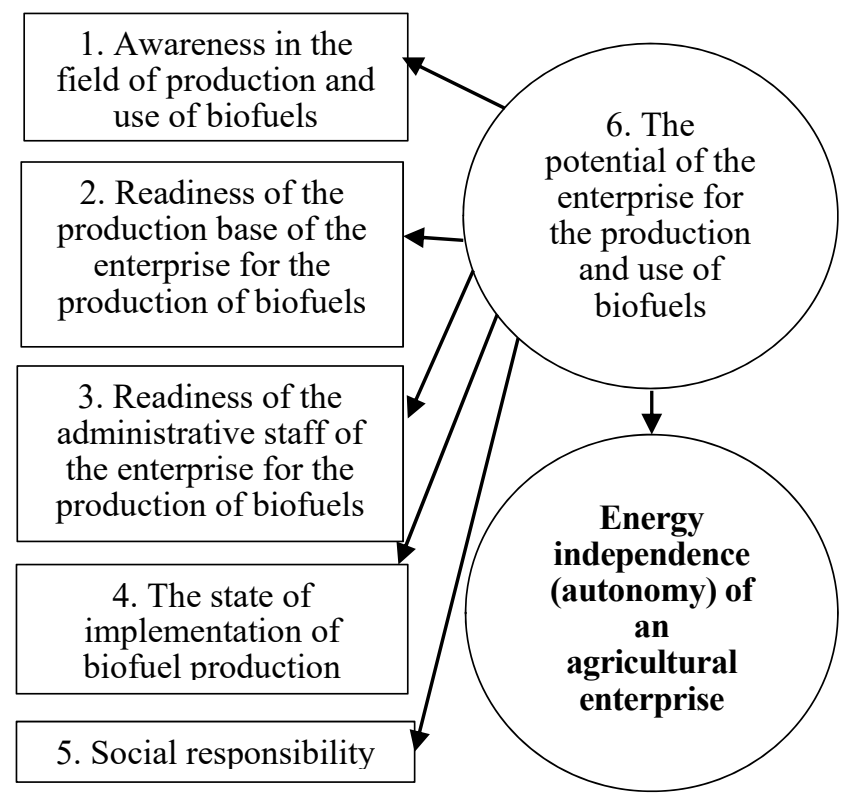

Figure 1. Conceptualization of research Source: compiled by the authors

The research was carried out by scientific and pedagogical workers of the National University of Bioresources and Environmental Management of Ukraine and Vinnitsa National Agrarian University. In the study, a questionnaire was used to collect data from the beginning of April to June 2020. Among the heads of agricultural enterprises in Ukraine, 400 questionnaires were distributed, 376 questionnaires 
were filled in and returned, of which 22 questionnaires were damaged, 354 questionnaires were found suitable for statistics. The largest group of respondents (147 respondents) 41.53\% were over the age of 50 . The next largest group (78 respondents) $22.03 \%$ were between the ages of 30 and 40. The next largest group of respondents (72 respondents) $20.34 \%$ from 40 to 50 years old and a small group of respondents who were under 30 years old (57 respondents) $16.1 \%$. In terms of educational level, with a secondary education diploma, $26.27 \%$ of respondents were surveyed (93 respondents). The largest group of respondents are respondents with a bachelor's degree (207 respondents) (58.47\%). Masters (specialists) made up (54 respondents) $15.26 \%$ of heads of agricultural enterprises (Table 1).

Table 1. Characteristics of the sample

\begin{tabular}{|l|c|c|}
\hline & Frequency & Percentage, $\%$ \\
\hline \multicolumn{3}{|c|}{$1-$ Age } \\
\hline Under 30 years & 57 & 16,1 \\
\hline From 30 to 40 years & 78 & 22,03 \\
\hline From 40 to 50 years & 72 & 20,34 \\
\hline Over 59 years 2 Level of education \\
\hline \multicolumn{3}{|c|}{ - 147,53} \\
\hline Secondary education & 93 & 26,27 \\
\hline Bachelor's degree & 207 & 58,47 \\
\hline Master's degree & 54 & 15,26 \\
\hline
\end{tabular}

Source: compiled by the authors

The questionnaires for this study contained two variables and were developed using measurement scales adopted from previous studies. These variables include the potential for the production and use of biofuels and the energy autonomy of the agricultural enterprise. The potential for the production and use of biofuels was measured against five criteria, according to which specific questions were developed: "Does your enterprise generate crop waste?", "Does your enterprise generate livestock by-products?", "Do you own the intellectual property rights for the production of biofuels?", "Does your enterprise have free funds that can be invested in innovations?", "Do you have integrated functions of innovation activity in the organizational structure of your enterprise?". The energy autonomy of an agricultural enterprise was measured according to six criteria with corresponding questions. For example: "A relatively small share of fuels and lubricants, electricity and natural gas in the production costs of your company". The measurements were carried out using a five-point Likert scale, where " 5 " means "strongly agree" and "1" means "strongly disagree".

\section{Results and Discussion}

The reliability of the research instrument (questionnaire) has been determined by two characteristics: stability and consistency. To measure the consistency of respondents' answers to the questionnaire, we used the Cronbach Alpha internal consistency test. The value of the test result indicates the degree of stability and can range from (0 to 1$)$, a value at the level of $60 \%$ and above is considered acceptable (Hair et al, 2006). The reliability indicators of the research instrument design are given in Table 2.

Table 2. Cronbach's Alpha test results

\begin{tabular}{|l|c|c|}
\hline \multicolumn{1}{|c|}{ Conceptual part } & $\begin{array}{c}\text { Number of } \\
\text { units }\end{array}$ & $\begin{array}{c}\text { Cronbach } \\
\text { Alpha }\end{array}$ \\
\hline $\begin{array}{l}\text { Potential for biofuel } \\
\text { production and use }\end{array}$ & 24 & 0.80 \\
\hline $\begin{array}{l}\text { Awareness of biofuel } \\
\text { production and use }\end{array}$ & 9 & 0.75 \\
\hline $\begin{array}{l}\text { Readiness of the production } \\
\text { base of the enterprise for the } \\
\text { production of biofuels }\end{array}$ & 4 & 0.83 \\
\hline $\begin{array}{l}\text { Readiness of the } \\
\text { administrative apparatus for } \\
\text { the production of biofuels }\end{array}$ & 4 & 0.78 \\
\hline $\begin{array}{l}\text { The state of the introduction } \\
\text { of biofuel production }\end{array}$ & 3 & 0.76 \\
\hline Social responsibility & 6 & 0.73 \\
\hline $\begin{array}{l}\text { Energy autonomy of an } \\
\text { agricultural enterprise }\end{array}$ & & \\
\hline
\end{tabular}

Source: compiled by the authors

The study began with exploratory factor analysis (EFA) to validate a proposed questionnaire to measure the potential for agricultural production and use of biofuels. The analysis was carried out using varimax transformation and major axis factoring. As a rule, elements with a load factor $(<0.5)$ are discarded. In this study, all elements had a load factor value $>0.5$.

In this study, the questionnaire was validated on the basis of the confirmatory factor analysis (CFA) method proposed for use in similar studies by Byrne [4] and Kline [12]. A second-order confirmatory factor model was used to validate the design based on the maximum likelihood method. Confirmatory factor analysis has been based on comparing the variance-covariance matrix obtained from the sample and the matrix obtained from the model (Table 3).

Table 3. Final statistical indices for the CFA model

\begin{tabular}{|c|c|}
\hline Model & EA \\
\hline $\mathrm{X} 2$ & 315.852 \\
\hline $\mathrm{df}$ & 72.3 \\
\hline $\mathrm{P}$ & 0.000 \\
\hline Cmidf & 4.368 \\
\hline RMSEA & 0.057 \\
\hline CFI & 0.905 \\
\hline P / Evaluation & $(0.62-0.97)$ \\
\hline All loadings were statistically significant at an alpha level \\
of $\mathrm{p}=0.05$ \\
\hline
\end{tabular}

Source: compiled by the authors 


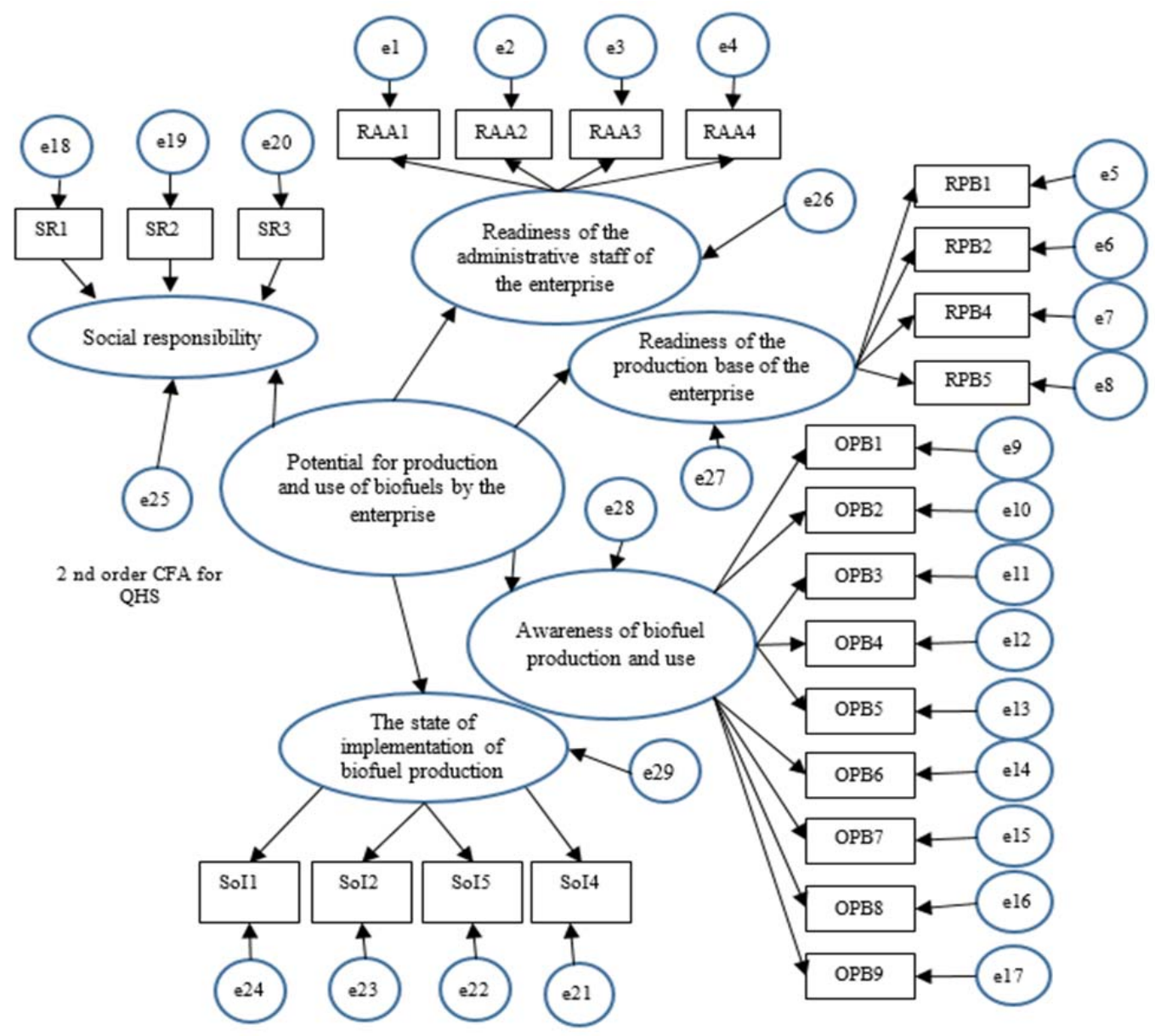

Figure 2. Block diagram of the second-order CFA modeling Source: compiled by the authors

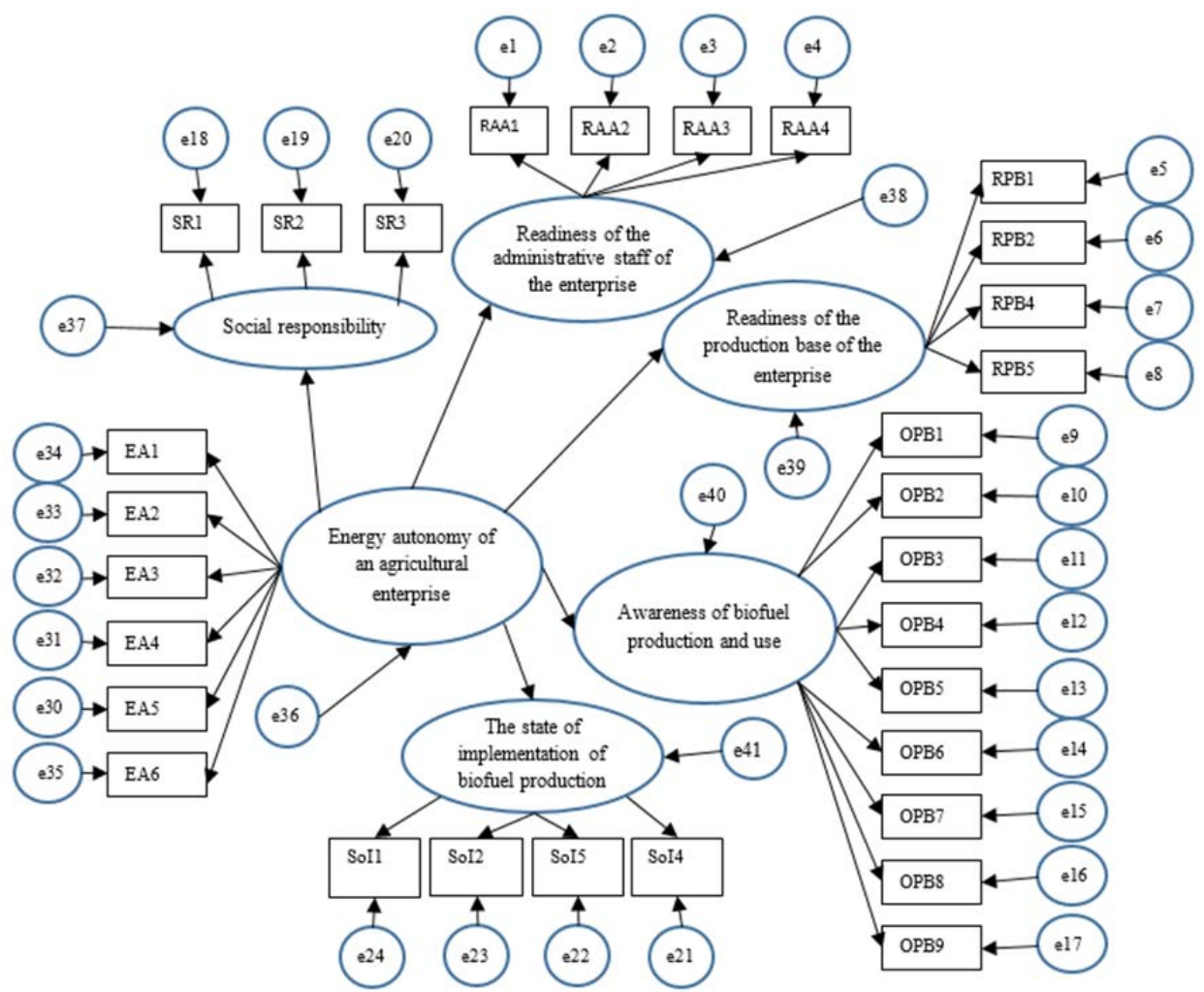

Figure 3. The complete structure of the model for assessing the awareness of heads of agricultural enterprises about the possibility of producing biofuels from waste

Source: compiled by the authors 
To test the hypothetical model shown in Figure 2 and Figure 3, for each of the measurements of potential for production and use of biofuels (PPUB) and energy autonomy of the agricultural enterprise, the indicator of variables were the relevant factors determined by the confirmatory factor analysis. Commonly used criteria for model suitability are xi square $\left(\mathrm{x}^{2}\right)$, suitability index (GFI), adjusted suitability index (AGFI), comparative suitability index (CFI), and standard error (RMSEA) [9], [13].

Table 4. Final statistical indices for the complete structure of the model

\begin{tabular}{|c|c|}
\hline Model & EA - energy autonomy \\
\hline $\mathrm{x}^{2}$ & 562.34 \\
\hline $\mathrm{df}$ & 148.82 \\
\hline $\mathrm{P}$ & 0.001 \\
\hline Cmidf & 3.778 \\
\hline RMSEA & 0.0602 \\
\hline CFI & 0.916 \\
\hline P/Evaluation & $(0.60-0.90)$ \\
\hline
\end{tabular}

Source: compiled by the authors

The data in Table 4 confirm the adequacy of the model. The xi -square rate (Cmin / df) is lower than 5 [2], RMSEA $<0.08$ and CFI $>0.9$ [3], which is acceptable. All parameters of the model are statistically significant and practically justified, the load factors ranged from 0.60 to 0.90 , which is greater than 0.5, as recommended [4]. The relationships between the two main variables are considered significant, Cmidf $>1.96$. All estimates are statistically significant and well-founded, and their value is an acceptable guide for proving the existence of direct and indirect relationships.

\section{Conclusion}

The results of a marketing study of a group of agricultural enterprises in Ukraine to determine the potential, awareness, and current state of use of agricultural waste to ensure energy autonomy of agricultural enterprises confirmed that the specific costs of agricultural enterprises for fuel and energy resources remain quite high. At the same time, agricultural enterprises generate a variety of wastes as a result of their main activity, which has a significant potential for biofuel production.

- The undertaken study is based on the results obtained earlier in the test sample of agricultural enterprises [21]. Comparison of the results obtained in this study with the results of previous studies showed the following:
- Costs of agricultural enterprises include on average about $20 \%$ of costs for fuel and energy resources (coal (2\%), natural gas (22\%), firewood for heating (2\%), gasoline (16\%), diesel fuel) $56 \%$ ), oils and lubricants $(2 \%)$ ), which confirms hypothesis 1 ;

- Agricultural enterprises are producers of byproducts (waste) of crop production (cereals $(80 \%)$, sugar beets - $(55 \%)$ and molasses $(45 \%)$, less important - potatoes $(35 \%)$, Jerusalem artichokes $(30 \%)$, chicory) 20\%)) and stockbreeding (animal manure $(85 \%$ of enterprises engaged in stockbreeding) and poultry manure $(45 \%$ of enterprises engaged in stockbreeding)), which confirms the potential of biofuel production and confirms hypothesis 2, 3 and 4. It should be noted that bird droppings, which are formed on poultry farms on a large scale, are a source of pollution of the atmosphere with ammonia, and the hydrosphere with ammonium ions. However, the spread of anaerobic fermentation technology with the formation of biogas allows you to fully realize the potential of energy or fuel production. Animal manure and bird droppings (chickens) are purchased by $20 \%$ of the surveyed enterprises for use in agriculture, as livestock waste, in compliance with harvesting technology, is the most concentrated and valuable organic fertilizer, which by its chemical composition is among the best types of organic fertilizers;

- The level of awareness about the possibilities of biofuel production based on waste is relatively satisfactory (on average, $70 \%$ of managers of surveyed enterprises have knowledge about biofuels and their advantages over traditional fuels and biofuels that can be created in the agricultural sector, and which of them can be produced by agricultural enterprises);

- Among $80 \%$ of managers of surveyed agricultural enterprises, the idea of possible incentives to organize biogas production through compensation of a certain part of the cost of construction of a biogas plant by the state or the possibility of obtaining soft loans for the construction of biogas reactors. There is also a need for educational work on the benefits of biogas production and use and the possibility of implementing projects at the level of individual agricultural enterprises;

- The main source of information on the possibilities of energy use of waste remained universities and the professional environment, which confirmed the refutation of hypothesis 6 ;

- $90 \%$ of managers of surveyed enterprises reported state support for organic production at a level sufficient for practical activities (legislation, support programs, tax, and other benefits, "green", which refutes hypothesis 7 . 
- The obtained results allow us to make the following generalizations:

- Volumes of waste generation in the studied enterprises are extremely high, which is due to the use of outdated technologies, high level of resource consumption;

- There is a tendency to increase the accumulation of agricultural waste, which causes a negative impact on the environment and public health. The peak of agricultural waste generation is in 2011 (at the level of 12.4 million tons), after which the volumes fall to the value of 2010 and in the period 2014-2016. In 2019, the volumes of waste generation increased compared to the previous two years and amounted to 6,7 million tons. The share of agricultural, forestry, and fishery waste in waste by type of economic activity and households in Ukraine ranges from $2-3 \%$;

- Positive trends in crop and livestock waste management among the surveyed enterprises are the reduction of waste disposal in specially designated places or facilities and their further storage in these places. However, for certain types of waste that can potentially serve as highly efficient raw materials for biofuel production (residues from tree pruning and planting care, cereal seeds of cereals and crops, excrement, urea, and livestock manure), the percentage of landfill remains quite significant;

- The researched enterprises are characterized by an inadequate level of waste used as secondary raw materials due to the inefficiency of organizational and economic approaches to their involvement in production;

- The level of energy use of agricultural waste in the studied enterprises remains low, bioenergy potential is lost;

- There are inefficiently implemented economic levers in the field of waste management of agricultural enterprises.

\section{References}

[1]. Berezyuk, S., Tokarchuk, D., \& Pryshliak, N. (2019). Economic and environmental benefits of using waste potential as a valuable secondary and energy resource. Journal of Environmental Management and Tourism.-2019.-Vol. X, Issue 1 (33).-P. 149-160. DOI: $10.14505 / /$ jemt.10.1(33).15

[2]. Bollen, K. A. (1989). Structural equations with latent variables (Vol. 210). John Wiley \& Sons. DOI:10.1002/9781118619179

[3]. Browne, M. W., \& Cudeck, R. (1992). Alternative ways of assessing model fit. Sociological methods \& research, 21(2), 230-258.

DOI:10.1177/0049124192021002005

[4]. Byrne, B. M. (2013). Structural equation modeling with LISREL, PRELIS, and SIMPLIS: Basic concepts, applications, and programming. Psychology Press.
[5]. Campbell, A., \& Doswald, N. (2009). The impacts of biofuel production on biodiversity: A review of the current literature. UNEP-WCMC, Cambridge, UK, 309-540.

[6]. Thrän, D., Naumann, K., Billig, E., Millinger, M., Oehmichen, K., Pfeiffer, D., ... \& Chiaramonti, D. (2017). Data on biofuels production, trade, and demand. In Biofuels production and processing technology (pp. 55-99). CRC Press.

[7]. Kour, D., Rana, K. L., Yadav, N., Yadav, A. N., Rastegari, A. A., Singh, C., ... \& Saxena, A. K. (2019). Technologies for biofuel production: current development, challenges, and future prospects. In Prospects of renewable bioprocessing in future energy systems (pp. 1-50). Springer, Cham.

[8]. Biofuels production, trade and sustainable development: emerging issues. Environmental Economics Programme, Sustainable Markets Discussion Paper No. 2, International Institute for Environment and Development (IIED), London

[9]. J. F. Hair, R. E. Anderson, R. L. Tatham, B. Babin, and B. Black (Eds.) (2005), Multivariate Data Analysis, 6th ed., 928 pp., Prentice-Hall, London.

[10]. Kaletnik, G., Honcharuk, I., \& Okhota, Y. (2020). The waste-free production development for the energy autonomy formation of Ukrainian agricultural enterprises. Journal of Environmental Management and Tourism.-2020.-Vol. XI, Summer, Issue 3 (43).-P. 513-522. DOI: $10.14505 / /$ jemt.v11.3(43).02

[11]. Khvesyk, M., Bystryakov, I., Obykhod, H., \& Khvesyk, Y. (2018). Assessment of the safety of environment in terms of sustainable development. Economic annals-XXI, (170), 22-26.

[12]. Kline, R. B. (2011). Principles and practice of structural equation modeling (3. Bask1). New York, NY: Guilford.

[13]. Lomax, R. G. (2018). Structural equation modeling: Multisample covariance and mean structures. In The reviewer's guide to quantitative methods in the social sciences (pp. 457-466). Routledge.

[14]. L.C. Basso, T.O. Basso, S.N. Rocha M.A.S. Bernardes. (2011), Biofuel production, InTech, Rijeka, pp. 85-100.

[15]. OECD-FAO Agricultural Outlook 2019-2028. Retrieved from: http://www.fao.org/3/CA4076EN/CA4076EN Chapte r9_Biofuels.pdf [accessed: 15 September 2021].

[16]. Olaganathan, R., Ko Qui Shen, F., \& Jun Shen, L. (2014). Potential and technological advancement of biofuels. International Journal of Advanced Scientific and Technical Research, 4(4), 12.

[17]. Patyka, N., Khodakivska, O., Pronko, L., Kolesnyk, T., Klymchuk, O., Kamenschuk, B., \& Zayed, N. M. (2021). Approaches To Evaluation of The Agriculture Competitiveness Level: Empirical Evidence In Ukraine. Academy of Strategic Management Journal, 20(1), 1-15.

[18]. Pronko, L., Furman, I., Kucher, A., \& Gontaruk, Y. (2020). Formation of a state support program for agricultural producers in Ukraine considering world experience. European Journal of Sustainable Development, 9(1), 364-364. 
[19]. Pryshliak, N., Lutsiak, V., Tokarchuk, D., \& Semchuk, I. (2020). The Empirical Research of the Potential, Awareness, and Current State of Agricultural Waste Use to Ensure Energy Autonomy of Agricultural Enterprises of Ukraine. Journal of Environmental Management and Tourism. 2020. Vol. XI.№ 7 (47). P. 1634-1648.

DOI: 10.14505/jemt. v11. 7 (47). 04.

[20]. Riazi, M. R., \& Chiaramonti, D. (Eds.). (2017). Biofuels production and processing technology. CRC Press.

[21]. Srivastava, N., Srivastava, M., Mishra, P. K., Upadhyay, S. N., Ramteke, P. W., \& Gupta, V. K. (2019). Sustainable Approaches for Biofuels Production Technologies. Springer International Publishing.
[22]. Stafford, W., Lotter, A., Brent, A., \& von Maltitz, G. (2017). Biofuels technology: A look forward (No. wp2017-87). World Institute for Development Economic Research (UNU-WIDER).

[23]. Thrän, D. (2015). Smart bioenergy. Technologies and concepts for a more flexible bioenergy provision in future energy systems. Springer, Leizpig

[24]. Tomchuk, O., Lepetan, I., Zdyrko, N., \& Vasa, L. (2018). Environmental activities of agricultural enterprises: accounting and analytical support. Economic annals-XXI, (169), 77-83. 